From the outset, Nature has been a kind of club in the best sense of that word. Its readers are also, potentially, its contributors. Many of its admitted idiosyncrasies are regularly forgiven by its familiars. Journalism, which at its best is a way (other than by research) of telling what the truth is, has been a crucial ingredient of Nature's style from the outset, and will remain so. The hope must be that the opportunities presented by technology for the more rapid dissemination of information can also be used so as to strengthen the sense of intimacy between editors, contributors and readers that has been this journal's special claim on professional attention for the past 125 years.

\section{All change in Brussels}

\section{The European Commission in the New Year will influence European science, but nobody can yet tell how.}

ONE of the quaint happenings in the European Union is that, from time to time, the old faces disappear, to be replaced by new ones. The next big upheaval will come in January, when several new people will come into office as members of the European Commission. As it happens, the commissioners responsible for science and industry are being changed. Most spectacularly, Signor Antonio Ruberti, who has managed the commission's research portfolio since the appointment of the last Italian government a year ago, is to be replaced by Mme Edith Cresson, who endured a turbulent brief spell in 1990 as the first woman to be the prime minister of France. It is also relevant and significant that Herr Martin Bangemann, a long-standing member of the commission and an adherent of the Free Democratic Party (FDP), the junior member of Germany's coalition government, becomes the commissioner responsible for industry, information technology and telecommunications; those are the fields in which much of the commission's research spending is concentrated.

So how will the new people shape up to their new responsibilities? Only guesswork can be a guide. But if Cresson feels like embarking on a scheme to do for Europe as a whole what the newly-elected French government did for France in 1980, she would have lots of people cheering for her. Unfortunately, it is more probable that she and Bangemann between them will be pushing for the continuation of the status quo, but for more of it. That would be a great misfortune. The trouble with Europe's research programme is that it has survived almost unchanged in its purpose since the first "framework" programme, which long predates the "Single Act" of 1986 that ushered in the now single market, not to mention the Maastricht Treaty, which speaks of the "coordination" of national research in Europe.

Will Cresson and Bangemann, between them, set about the radical review of Europe's research that the circumstances demand? That is where they should put their energy. And this is how they should set about the job. First, they should recognize that many of the principles on which existing projects are based have been overtaken by events. Can it still make sense, for example, to require that applica- tions for projects in applied research, in information technology or telecommunications, should include partners from at least two and preferably more countries, when the single market decrees that commercial organizations be given every opportunity to drive each other into the ground? The commission would be sharply criticized if it abandoned the practice, but not on grounds of principle. National governments would simply complain that they and their constituents had been left out.

Second, Cresson and Bangemann should accept that the chief purpose of central spending on research by the commission will be, for the next ten years at least, the broadening and deepening of Europe's high-level technical skills. That argues, first, for supporting basic research as a priority, and applied research if there are funds left over. As things are, there are too many parts of Europe in which academic institutions are only indifferently engaged in contemporary science - and many others in which Europe's capacity to match insight with tangible (and perhaps patentable) discovery is comparatively impoverished. Cresson and Bangemann could do worse than begin by commissioning a study of what Europe's academic institutions have to offer in advanced skill - and then heeding the implications for improved highlevel training in discovery and research.

Third, Cresson-Bangemann should look for a way of getting the bureaucracy off the back of European science. That is not to fall into the trap of suggesting that the Brussels bureaucracy is an army of overpaid international public servants with so much time on its hands that it can interfere in minor matters. On the contrary, the army is too small to discharge even routine tasks properly - announcing competitive awards of research funds in time for those likely to be interested to complete meaningful applications before the deadlines pass, for example. But the research community, which is well networked, is excellent at tasks of which the commission regularly makes a muddle. Cresson-Bangemann should resolve to delegate more of their evaluation to sympathetic external organizations, keeping to the commission the responsibility for strategy which it cannot dodge.

Cresson-Bangemenn should also be careful to talk at length to Ruberti before he disappears. Unlike too many of his predecessors, Ruberti has not sought to put his stamp on the commission's research programme as a whole, and in too little time. Instead, he has been concerned with the infrastructure of research (the new data-centre at Seville is an example) and with trying to ensure that some things work a little better. That may not be much to boast about, but it is a lot better than the scant attention the commission's research arm has traditionally paid to the administration of research.

What Cresson-Bangemann should aim at is what Europe has been hungering for since the end of the Second World War: the resources with which to clothe its view of what the world is like with proof that the view corresponds with reality. The temptation, for Cresson-Bangemann, will be to look for yet another gimmick with which to fire the European imagination - an even faster train-set for adult passengers, for example. Far better to start by making a fair contribution to the understanding of the world we live in. 